\title{
How much evidence is enough? A public health perspective on evidence-informed tobacco policy
}

\section{De combien de preuves avons-nous besoin? Une perspective de santé publique sur la politique antitabac éclairée par les données probantes}

\author{
Robert Schwartz ${ }^{1,2,3,4,5}$ \\ Published online: 28 October 2019 \\ (C) The Canadian Public Health Association 2019
}

The authors of "Health-related quality of life and economic burden related to smoking behaviour among Canadians" (Cui et al. 2019) call for more tobacco control in order to both improve health-related quality of life (HRQoL) and generate social returns on investment. This, based on their economic analysis of data on the health effects and costs of tobacco use in Canada. Thanks for yet another nail in the coffin of the commercial tobacco enterprise. Yes, researchers should generate more and more strong evidence. There is, it seems, at least some continued appetite from granting agencies to fund studies on the harms of tobacco and from journals to publish results. Is there such a thing, though, as enough evidence?

Do we know enough about the harms of tobacco? Enough for what, one might ask? Enough for people to stop smoking tobacco? Enough for governments to prohibit the growing, manufacture, and sale of tobacco? We certainly know a great deal. We know that cigarette smoking kills at least half of

Robert Schwartz

robert.schwartz@utoronto.ca

1 Ontario Tobacco Research Unit, University of Toronto, Toronto, ON, Canada

2 Strategy Design and Evaluation Initiative, University of Toronto, Toronto, ON, Canada

3 Centre for Addiction and Mental Health, University of Toronto, Toronto, ON, Canada

4 U of T Collaborative Specialization in Public Health Policy, University of Toronto, Toronto, ON, Canada

5 Dalla Lana School of Public Health, Institute of Health Policy, Management \& Evaluation, University of Toronto, Toronto, ON, Canada long-term users. We know that it causes cancer, heart disease, stroke, lung diseases, COPD, and diabetes (US Department of Health and Human Resources 2014). We know that it costs Canada some $\$ 18.7$ billion each year, including $\$ 6.4$ billion in health-care costs (Krueger et al. 2015).

We know enough for governments to act. Indeed, since the 1970s, governments have sought to reduce tobacco use, and in 2005 the Framework Convention on Tobacco Control became the first international treaty in public health. Tobacco control has focused largely on the demand side to discourage people from smoking through public education, health warnings, smoking bans in public places and workplaces, and taxation. Some supply-side measures restrict the ability of the industry to sell tobacco, including bans on sales to minors, marketing restrictions, and total display bans at retail.

Tobacco control, however, has not ended the blight of commercial tobacco. Perhaps the name tells it all. It seems that the undertaking is about controlling tobacco, not about ending it. Despite some 50 years of tobacco control in Canada, one in five Canadians still use tobacco (past 30 days, all tobacco use) (Ontario Tobacco Research Unit 2018). Great progress from upwards of $40 \%$ tobacco usage in the 1970s to downwards of $20 \%$ in 2019. What is going on here? Is it that we have enough evidence to act, but not enough to act with sufficient effectiveness? Well, we do have a set of tobacco control policies whose effectiveness has been studied broadly and deeply. Systematic reviews, reviews of reviews, and expert panel review of these provide effect sizes (or at least ranges of effect sizes) for classic tobacco control policies like taxation, smoking bans, and marketing restrictions (Smoke-Free Ontario Scientific Advisory Committee 2017). Nevertheless, the levels at which these policies have been implemented in Canada (and elsewhere) have 
proven insufficient to decrease tobacco use rates beyond current levels. Newer measures like flavour restrictions, menthol bans, and plain packaging are expected to make a dent, but not a fatal blow.

The general population and a substantial proportion of smokers find the state of tobacco and tobacco control to be unacceptable (Chung-Hall et al. 2018). Indeed, even the Government of Canada seems to agree and has adopted a tobacco endgame policy of less than $5 \%$ tobacco use by 2035. But why wait until then? Waiting until 2035 will result in some 650,000 more deaths and an additional $\$ 250$ billion in societal and health-care costs (Zhang and Schwartz 2013). Even tobacco companies have declared their desire to get out of the business of combustible cigarettes (Philip Morris International 2019).

Do we not have enough evidence to call tobacco companies on their bluff? How many more studies like that of Cui et al. (2019) do we need to fund, conduct, review, and read before the government takes bold and politically wise action? Yes-stop the sale of this deadly product. Not overnight. Give the industry and smokers a reasonable period of time to adapt and adjust. How about three years? This is not a radical idea. We have done it for leaded gas. We have done it for incandescent light bulbs. Especially as there is a viable alternative for those addicted to nicotine - in the form of electronic cigarettes - this should be a mainstream idea.

Where we do not yet have enough evidence is about these alternative nicotine delivery devices. Funders are recognizing this, researchers are busy producing evidence, and journals are publishing lots of it. Scientists generally agree that we know enough to invoke the precautionary principle so as to prevent non-smoking youth and young adults from becoming longterm regular e-cigarette users. Precursors and markers for respiratory disease, cardiac effects, and cell toxicity have been found in lab, animal, and a few human studies (National Academies of Sciences, Engineering, and Medicine (NASEM) 2018). Enough is known about nicotine to recommend that young people stay away from it as it affects brain development. Enough is known to conclude that vaping of nicotine cigarettes creates dependence. Enough is known for governments to act strongly to prevent ecigarette use by young people.

Is there enough evidence about the harm reduction potential of e-cigarettes? While some in the United Kingdom have claimed that e-cigarettes are $95 \%$ safer than combustible cigarettes, others argue that there is no evidence for this claim. Some suggest that their preliminary findings might indicate that e-cigarettes are no less harmful than cigarettes.

For me, the choice between a product whose harm is well proven and a product that may reduce harm substantially is clear. Is there enough evidence for governments to promote ecigarettes to smokers who cannot quit? Once switched to e-cigarettes, is there evidence about how to help people quit vaping as well?
Thanks again to Cui and colleagues for an additional nail in the commercial tobacco coffin. Governments should need no more nails to do what they know should be done. Research and policy focus should then turn to the alternative products with the hope that prudent evidence-informed policy will prevent the next round of researchers and journal editors from having to report on significant HRQoL loss and economic burden of e-cigarette use.

\section{Éditorial}

Les auteurs de l'article « Health-related quality of life and economic burden related to smoking behaviour among Canadians » (Cui et coll. 2019) réclament davantage de mesures antitabac pour améliorer la qualité de vie liée à la santé (QVLS) et dégager des rendements sociaux sur le capital investi. Ils fondent leurs demandes sur une analyse économique des données sur les coûts du tabagisme au Canada et ses effets sur la santé. C'est un énième clou dans le cercueil du tabac commercial, ce pour quoi nous les remercions. Oui, les chercheurs doivent continuer de produire des preuves solides. Il y a, semble-t-il, au moins encore un certain appétit chez les organismes de subvention pour le financement d'études sur les méfaits du tabac, et chez les revues scientifiques pour la publication des résultats de ces études. Existe-t-il toutefois une telle chose que des preuves suffisantes?

En savons-nous assez sur les méfaits du tabac? Assez pour quoi, peut-on se demander? Assez pour que les gens cessent de fumer du tabac? Assez pour que les gouvernements en interdisent la culture, la fabrication et la vente? Nous en savons certainement beaucoup. Nous savons que l'usage de la cigarette tue au moins la moitié des fumeurs à long terme. Nous savons qu'il cause cancers, cardiopathies, AVC, pneumopathies, MPOC et diabète (US Department of Health and Human Resources 2014). Nous savons que le tabagisme coûte au Canada quelque 18,7 milliards de dollars par année, dont 6,4 milliards en coûts de soins de santé (Krueger et coll. 2015).

Nous en savons assez pour que les gouvernements agissent. À vrai dire, depuis les années 1970, ils cherchent à réduire le tabagisme, et en 2005, la Convention-cadre pour la lutte antitabac est devenue le premier traité international de santé publique. La lutte antitabac porte principalement sur la demande; par la sensibilisation, les mises en garde sanitaires, les interdictions de fumer dans les lieux publics et de travail et les mesures fiscales, elle vise à dissuader les gens de fumer. Seule une poignée de mesures axées sur l'offre limite la capacité de l'industrie de vendre du tabac : l'interdiction de vendre aux personnes mineures, les restrictions à la commercialisation et l'interdiction totale de l'étalage au détail.

La lutte antitabac n'a toutefois pas mis fin au fléau du tabac commercial. Le nom l'indique : nous luttons encore, et la guerre n'est pas gagnée. Malgré une cinquantaine d'années de lutte au Canada, une personne sur cinq au Canada 
consomme encore du tabac (30 jours antérieurs, toutes formes de tabagisme) (Unité de recherche sur le tabac de l'Ontario 2018). Admettons qu'il y a eu des progrès considérables : l'usage du tabac, qui était de plus de $40 \%$ dans les années 1970, est de moins de $20 \%$ en 2019. Mais que se passe-t-il vraiment? Est-ce que nous avons assez de preuves pour agir, mais pas assez pour agir avec suffisamment d'efficacité? Nous avons bien un jeu de politiques antitabac dont l'efficacité a été étudiée sous toutes ses coutures. Des revues systématiques, des revues de revues, et des examens de ces revues par des commissions d'experts présentent les ampleurs de l'effet (ou du moins les intervalles d'ampleurs de l'effet) des politiques antitabac classiques comme la taxation, les interdictions de fumer et les restrictions à la commercialisation (comité consultatif scientifique d'Ontario sans fumée 2017). Néanmoins, les niveaux auxquels ces politiques sont appliquées au Canada (et ailleurs) se révèlent insuffisants pour réduire les taux de tabagisme en-deçà des seuils actuels. Des mesures plus récentes, comme les restrictions sur les arômes, l'interdiction des produits mentholés et le conditionnement neutre, devraient laisser une marque, mais ne porteront pas le coup de grâce.

La population générale et une importante proportion de fumeurs trouvent que la situation du tabac et de la lutte antitabac est inacceptable (Chung-Hall et coll. 2018). Même le gouvernement du Canada semble d'accord et a adopté une politique de sortie du tabac qui vise un seuil de moins de $5 \%$ de tabagisme d'ici 2035. Mais pourquoi attendre? D'ici 2035, il y aura eu quelque 650000 décès évitables et 250 milliards de dollars de plus en coûts sociétaux et de soins de santé dus au tabagisme (Zhang and Schwartz 2013). Même des fabricants de produits du tabac expriment le souhait de se retirer du commerce des cigarettes combustibles (Philip Morris International 2019).

N'avons-nous pas suffisamment de preuves pour mettre les fabricants de produits du tabac au pied du mur? Combien d'autres études comme celle de Cui et collègues (2019) faudrat-il financer, mener, examiner et lire avant que le gouvernement prenne des mesures audacieuses et politiquement judicieuses? Oui - mettons fin à la vente de ce produit mortel. Pas du jour au lendemain. Laissons à l'industrie et aux fumeurs un délai raisonnable pour s'adapter et s'ajuster. Pourquoi pas trois ans? L'idée n'a rien de radical. Nous l'avons fait pour l'essence au plomb. Nous l'avons fait pour les ampoules incandescentes. Comme, en plus, il existe une option de rechange viable pour les personnes dépendantes de la nicotine - les cigarettes électroniques - l'idée devrait faire consensus.

C'est au sujet de ces dispositifs d'apport de nicotine qu'il nous manque encore des données probantes. Les bailleurs de fonds en sont conscients, les chercheurs s'affairent à en produire, et les revues scientifiques publient beaucoup sur le sujet. Les scientifiques conviennent dans l'ensemble que nous en savons assez pour invoquer le principe de précaution et empêcher les jeunes et les jeunes adultes non fumeurs de devenir à long terme des utilisateurs réguliers de cigarettes électroniques. Des précurseurs et des marqueurs de maladies respiratoires, d'effets cardiaques et de toxicité cellulaire ont été observés dans des études menées en laboratoire et sur des animaux et dans quelques études sur des humains (National Academies of Sciences, Engineering, and Medicine [NASEM] 2018). Nous en savons assez sur la nicotine pour recommander que les jeunes n'en consomment pas, car elle nuit au développement du cerveau. Assez pour conclure que le vapotage de cigarettes à la nicotine crée une dépendance. Et assez pour que les gouvernements prennent des mesures vigoureuses pour prévenir l'utilisation des cigarettes électroniques chez les jeunes.

Y a-t-il suffisamment de preuves sur les cigarettes électroniques et leur potentiel de réduction des méfaits? Certaines voix aux Royaume-Uni prétendent que ces cigarettes sont $95 \%$ moins dangereuses que les cigarettes combustibles, mais d'autres font valoir qu'une telle allégation ne repose sur aucune preuve. D'autres encore indiquent que selon leurs constatations préliminaires, les cigarettes électroniques pourraient être tout aussi nocives que les cigarettes classiques.

Pour moi, le choix entre un produit dont les méfaits sont largement prouvés et un produit qui pourrait considérablement réduire les méfaits est clair. Y a-t-il suffisamment de preuves pour que les gouvernements fassent la promotion des cigarettes électroniques auprès des fumeurs qui n'arrivent pas à cesser de fumer? Une fois qu'ils seront passés aux cigarettes électroniques, aurons-nous des données probantes sur les moyens de les aider à cesser de vapoter aussi?

Merci encore à Cui et collègues pour ce clou supplémentaire dans le cercueil du tabac commercial. Les gouvernements ne devraient pas avoir besoin d'autres clous pour faire ce qu'ils savent qu'il faut faire. Les démarches de recherche et d'élaboration de politiques devraient donc se tourner vers les produits de rechange, dans l'espoir qu'une politique prudente et éclairée par la science empêche le prochain groupe de chercheurs et de rédacteurs de revues d'avoir à faire état de la perte considérable de QVLS et du lourd fardeau économique associés à l'utilisation des cigarettes électroniques.

\section{References/Références bibliographiques}

Chung-Hall, J., Fong, G. T., Driezen, P., \& Craig, L. (2018). Smokers' support for tobacco endgame measures in Canada: findings from the 2016 International Tobacco Control Smoking and Vaping Survey. CMAJ Open., 6(3), E412-E422. https://doi.org/10.9778/cmajo. 20180025 Print 2018 Jul-Sep.

Cui, Y., Forget, E. L., Torabi, M., Oguzoglu, U., Ohinmaa, A., \& Zhu, Y. (2019). Health-related quality of life and economic burden related to smoking behaviour among Canadians. Canadian Journal of Public Health, 110, 5. https://doi.org/10.17269/s41997-019-00244-x. 
Krueger H, Krueger J, Koot J. Variation across Canada in the economic burden attributable to excess weight, tobacco smoking and physical inactivity. Canadian Journal of Public Health. 2015: 106(4):e171e177.

National Academies of Sciences, Engineering, and Medicine (NASEM). (2018). Public health consequences of e-cigarettes. Washington, DC: The National Academies Press. https://doi.org/10.17226/ 24952.

Ontario Tobacco Research Unit. (2018). Smoke-Free Ontario Strategy Monitoring Report. Toronto: Ontario Tobacco Research Unit, Special Report.

Philip Morris International. https://www.pmi.com/who-we-are/ designing-a-smoke-free-future. Accessed 25 Aug 2019.

Smoke-Free Ontario Scientific Advisory Committee. (2017). Ontario Agency for Health Protection and Promotion (Public Health Ontario). In Evidence to guide action: comprehensive tobacco control in Ontario (Vol. 2016). Toronto: Queen's Printer for Ontario.
U.S. Department of Health and Human Services. (2014). The health consequences of smoking -50 years of progress: a report of the surgeon general. Atlanta: U.S. Department of Health and Human Services, Centers for Disease Control and Prevention, National Center for Chronic Disease Prevention and Health Promotion, Office on Smoking and Health.

Zhang, B., \& Schwartz, R. (2013). The effect of tobacco control strategies and interventions on smoking prevalence and tobacco attributable deaths in Ontario, Canada: technical report of the Ontario SimSmoke. Toronto: Ontario Tobacco Research Unit, Special Report.

Publisher's note Springer Nature remains neutral with regard to jurisdictional claims in published maps and institutional affiliations. 